\title{
OVULINIA PETAL BLIGHT ON AZALEA AND RHODODENDRON IN NEW ZEALAND
}

\author{
B.J.R. ALEXANDER ${ }^{1}$, S. GANEV ${ }^{1}$, M. BRAITHWAITE ${ }^{1}$ and J.C. HURRELL ${ }^{2}$

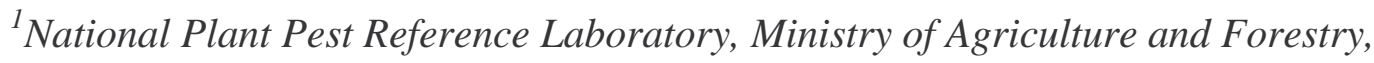 \\ PO Box 24, Lincoln, New Zealand \\ ${ }^{2}$ AgriQuality New Zealand Assurance Services, PO Box 41, Auckland, New Zealand
}

Ovulinia petal or flower blight, caused by the fungus Ovulinia azaleae Weiss, is considered one of the most devastating diseases of azalea and rhododendron. The disease was first reported on azalea in the USA in 1931 and later in Australia, Japan, and in several countries in Europe. Ovulinia petal blight was also reported in overseas literature as being present in New Zealand; however, a search of New Zealand's records did not substantiate this claim. In November 1996, O. azaleae was isolated from infected azalea flowers collected from a North Island nursery. This was the first formal report of the disease in New Zealand. In a subsequent survey, a total of 52 sites (45 retail garden centres and seven specialist nurseries) were examined for petal blight in Auckland, Taranaki, Wanganui, Wellington, and Mid Canterbury on a range of azalea and rhododendron cultivars. The survey was conducted in September and October 1997 when most azaleas and rhododendrons were in full flower. $O$. azaleae was detected at $52 \%$ of the sites surveyed; $58 \%$ of cultivars at those sites were infected with the fungus. $O$. azaleae was recovered from three of the seven specialist nurseries surveyed. The disease was widespread on North Island sites, but was not detected at any of the Mid Canterbury sites. Unfavourable environmental conditions for disease development may have accounted for the fungus not being detected in Mid Canterbury.

\section{THE EFFECT OF NON SPORE FORMING FUNGI (MYCELIA STERILIA) ON GERMINATION AND GROWTH OF COMMON LEGUMINOUS AND GRAMINEACOUS PASTURE PLANTS}

\author{
N.W. WAIPARA ${ }^{1}$, M.E. DI MENNA ${ }^{1}$, A.L.J. COLE ${ }^{2}$ and R.A. SKIPP ${ }^{3}$ \\ ${ }^{1}$ AgResearch, Ruakura Research Centre, Private Bag 3123, Hamilton, \\ ${ }^{2}$ Plant and Microbial Sciences, University of Canterbury, Private Bag 4800 Christchurch \\ ${ }^{3}$ AgResearch Grasslands, Private Bag 11008, Palmerston North
}

Non spore forming fungi comprised $40 \%$ of fungal isolates obtained from pasture plant roots. Representative isolates from distinguishable non-spore forming taxonomic groups were assessed in a series of laboratory and pot experiments for plant growth promotion (PGP) or pathogenicity to seed, seedlings and plants, of eight economically important pasture species. Mycelium of most isolates readily penetrated root tissues but had no observed effect on plant growth. However some isolates had a beneficial effect on plant growth, as colonised plants recorded significantly higher root and shoot growth than uninoculated controls. A smaller component of these PGP isolates were also observed to enhance seedling emergence in the presence of two seed pathogens Botrytis cinerea and Fusarium equiseti. Pathogenic isolates comprised $12 \%$ of tested fungi and were observed to inhibit root elongation, act as causal agents of seedling root rot and significantly lowered both shoot and root dry weights. 